\title{
BASAL SEQUENCES OF TERRIGENOUS, CARBONATE, AND SALT-BEARING FORMATIONS AND THEIR ROLE IN THE STRUCTURE OF SEDIMENTARY BASINS IN RELATIONS TO FORECAST OF ECONOMIC MINERALS
}

\author{
S.A. Matchoulina, S.B. Shekhunova
}

\section{БАЗАЛЬНЫЕ ТОЛЩИ ТЕРРИГЕННЫХ, КАРБОНАТНЫХ И СОЛЕНОСНЫХ ФОРМАЦИЙ И ИХ РОЛЬ В СТРОЕНИИ ОСАДОЧНЫХ БАССЕЙНОВ В СВЯЗИ С ПРОГНОЗИРОВАНИЕМ ПОЛЕЗНЫХ ИСКОПАЕМЫХ}

\author{
С.А. Мачулина, С.Б. Шехунова
}

The authors describe the structure regularities and determine the lithological and geophysical criteria for recognition of basal sequences in terrigenous, carbonate, and salt-bearing formations of the Dnieper-Donets Depressions and other petroleumbearing regions of Ukraine. The basal sequences are considered as potential reservoirs of oil and gas.

Описаны закономерности строения и определены литологические и геофизические критерии выделения базальных толщ в терригенных, карбонатных и соленосных формациях Днепровско-Донецкой впадины и других нефтегазоносных регионов Украины.

\section{ПОСТАНОВКА ПРОБЛЕМЫ}

При расчленении осадочного чехла любого нефтегазоносного бассейна методами циклического анализа необходимо выделять базальные толщи, которые залегают в основании преимущественно трансгрессивных циклов разного ранга. Базальные толщи являются не только важным критерием цикличности разреза и перерыва в осадконакоплении, но, также, представляют значительный практический интерес как породы-коллекторы повышенной емкости, которые могут содержать залежи нефти и газа. Однако вопросы методики выделения базальных толщ в разрезах, особенности строения и литологической характеристики недостаточно освещены в научной литературе. О значении базальных толщ для нефтегазоносности осадочного чехла Днепровско-Донецкой впадины (ДДВ) писали Н.Я. Зайковский и М.Г. Егурнова [6, 8]. Авторы охарактеризовали базальные толщи, расположенные на границах крупных циклов осадконакопления (девон-карбон, карбон-пермь), впервые привели их геофизическую характеристику и отметили региональное распростронение и нефтегазоносность. В дальнейшем эти работы позволили разработать методику расчленения и корреляции продуктивных горизонтов ДДВ [3] и перенести этот опыт в другие нефтегазоперспективные регионы Украины (Северное Причерноморье, Волыно-Подолию) [11, 12].

Примеры высокой продуктивности базальных толщ известны из практики освоения крупных нефтегазоносных бассейнов мира. Так, например, залежи нефти приурочены к базальным толщам четырёх тектоно-седиментационных циклов (ранне-среднеюрскому, келловей-оксфордскому, кимеридж-барремскому и апт-сеноманскому) территории Сургутского нефтегазоносного района Западно-Сибирской плиты, которые имеют близкое строение, мощность (100-150 м) и сложены песчано-алевролитовыми породами морского мелководья. Все базальные толщи перекрываются аргиллитоподобными глинами в разной степени битуминозными [1]. Крупные скопления нефти и газа содержатся в базальных грубозернистых гравийных аркозах пенсильванского возраста месторождения Ланхендл-Хьтотон Северной Америки. В Северной Африке нефтеносны базальные песчаники позднего мела ливийских месторождений Сарир и Амал. Они залегают на склонах горстообразных выступов кристаллического фундамента, кора выветривания которого на месторождении Ауджила также нефтеносна [7]. Подобные примеры нефтегазоносности базальных толщ, лежащих на породах коры выветривания протерозойского фундамента, известны на месторождениях прибортовых и бортовых зон ДДВ и северной окраины Донбасса. В таких случаях базальная толща и кора выветривания кристаллического фундамента представляют собой вещественное выражение перерыва в осадконакоплении [6]. 


\section{С.А. МАЧУЛИНА, С.Б. ШЕХУНОВА}

Базальные толщи присутствуют в формациях разного литологического состава (терригенных и терригенно-карбонатных, преимущественно карбонатных и сульфатно-карбонатных, соленосных и др.). Базальные толщи вместе с покрывающими их глинистыми пластами могут быть достаточно уверенно идентифицированы на диаграммах стандартного и радиоактивного каротажа и служить региональными реперами при корреляции разрезов скважин, особенно в платформенных областях, где по латерали их литологическая характеристика и мощности относительно выдержаны. В рифтогенных структурах с длительной историей формирования и расчлененным рельефом дна бассейна их литологический состав изменчив, а мощности варьируют. Нередко, в силу тектонических причин, базальные толщи могут отсутствовать, быть частично или полностью размытыми, но их присутствие в разрезе всегда служит признаком несогласия или перерыва в осадконакоплении.

Таким образом, базальные толщи позволяют более обоснованно расчленить разрез на разноранговые седиментационные циклы и ритмы, содержащие продуктивные и перспективные горизонты, глинистые покрышки и соленосные экраны, что способствует построению прогнозных карт нефтегазоносности.

В статье рассматриваются некоторые новые закономерности образования базальных толщ в палеозойских отложениях ДДВ и других регионах Украины. Особое внимание уделено опыту выделения базальных толщ по данным ГИС и керна в сложнопостроенных соленосных разрезах ДДВ.

\section{БАЗАЛЬНЫЕ ТОЛЩИ ТЕРРИГЕННЫХ И КАРБОНАТНЫХ ФОРМАЦИЙ ПАЛЕОЗОЙСКИХ ОТЛОЖЕНИЙ НЕФТЕГАЗОНОСНЫХ РЕГИОНОВ УКРАИНЫ}

Известно, что с позиций цикличности палеозойские отложения ДДВ и других нефтегазоносных регионов Украины представляют собой иерархически построенную систему трансгрессивно-регрессивных (нередко редуцированных) седиментационных циклов и ритмов, осложненных межформационными и внутриформационными перерывами в осадконакоплении $[2,4,5,9,11]$. Практика выделения базальных толщ в разноранговых седиментационных циклах ДДВ, Преддобруджинского прогиба и Волыно-Подолии позволяет сформулировать следующую закономерность. Базальные толщи, которые располагаются в основании трансгрессивных циклов, подчиняются закону иерархии. Ранг базальной толщи определяется рангом циклической единицы, к основанию которой она приурочена. Поскольку базальные толщи связаны с перерывами в осадконакоплении, эта же закономерность справедлива и в отношении последних. Продемонстрируем иерархичность базальных толщ несколькими примерами.

В строении Волыно-Подольской нефтегазоносной провинции выделяются базальные лагунноконтинентальная горбашовская (венд, волынская серия) и байосско-батская (средняя юра, Стрыйский прогиб) толщи, являющиеся базальными соответсвенно для каледонского и альпийского мегациклов. Среднеюрские пестроцветные глинистые лагунно-континентальные образования представляют интерес в связи с возможной бокситоносностью [5].

В ДДВ в основании турнейско-нижневизейского трансгрессивного макроцикла залегает высокопродуктивная базальная толща, представленная в центральной части впадины конгломератовидными и разнозернистыми песчаниками турнейского возраста. В Сребненском прогибе турнейская базальная толща имеет двучленное строение; ей соответствуют продуктивные горизонты Т-1 и Т-2 (здесь и далее номенклатура продуктивных горизонтов приведена по работе [3]), которые образуют на Тимофеевском, Яблуновском и других месторождениях массивные нефтегазоносные залежи. Мощность турнейской базальной толщи в наиболее полных разрезах составляет 80-100 м (например, в скв. Яблуновская - 3). В основании циклов более низкого ранга, например в нижневизейском и верхневизейском мезоциклах, залегают продуктивные базальные горизонты В-26 и В-21, соответственно. На Юрьевской площади (скв. 6) из базального горизонта В-26, мощностью 10 м, получен промышленный приток газа 388 тыс м³ $/$ сут; а из горизонта В-21 - 830 тыс м³/сут (рис. 1, а). Коллекторы этих базальных толщ представлены в нижней части обломочной породой смешанного песчано-карбонатного состава, поскольку подперерывные толщи сложены мелководными известняками, а в верхней - песчаниками. Базальный горизонт В-21 высокопродуктивен, также, на Бугреватовском месторождении. В Бугреватовской скв. 22 из него получено 160 т нефти, а в скв.12 - 36 т нефти. На Анастасьевской площади (скв.3) из этого же базального горизонта, мощностью всего лишь 13 м, получен приток 600 тыс м³/сут газа. На Бугреватовском и Анастасьевском месторождениях продуктивный базальный горизонт В-21 

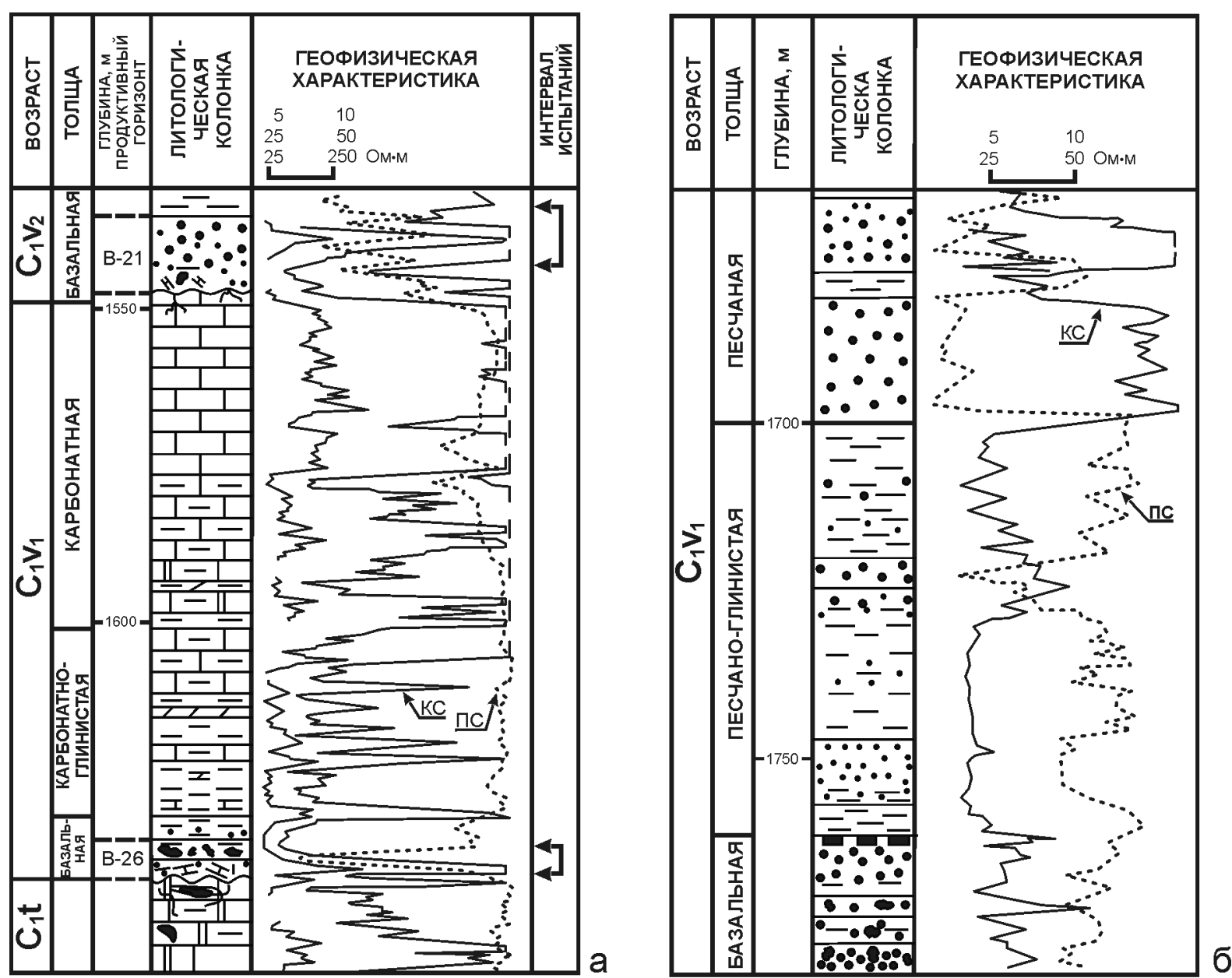

УСЛОВНЫЕ ОБОЗНАЧЕНИЯ

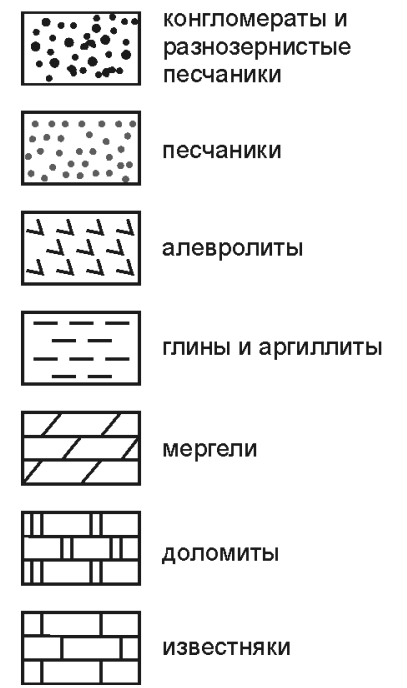

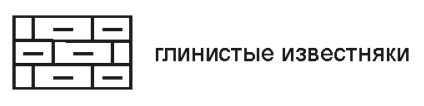

$\hat{\wedge} \wedge \hat{\wedge} \wedge$ ангидриты

$\bar{\wedge} \overline{-} \bar{\wedge} \hat{-}$ глинистые ангидриты

nnn $n$ соли

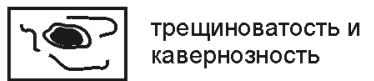

- - углистый пласт

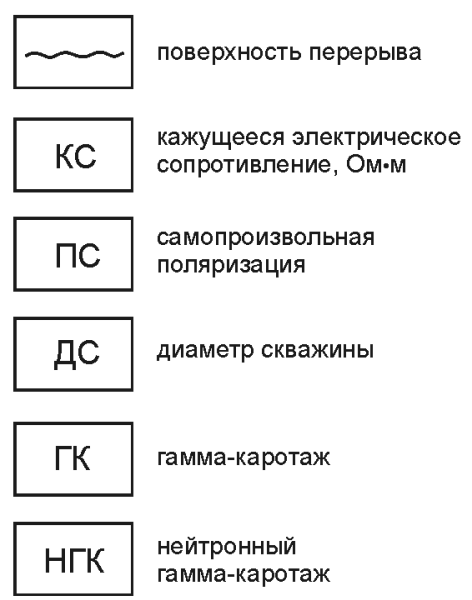

гамма-каротаж

Рис. 1. Базальные толщи в терригенных формациях: а - ДДВ, Юрьевская площадь; б - ДДВ, Пролетарская площадь; в - базальные толщи в сульфатно-карбонатной формации, Западное Причерноморье, Преддобруджский прогиб 


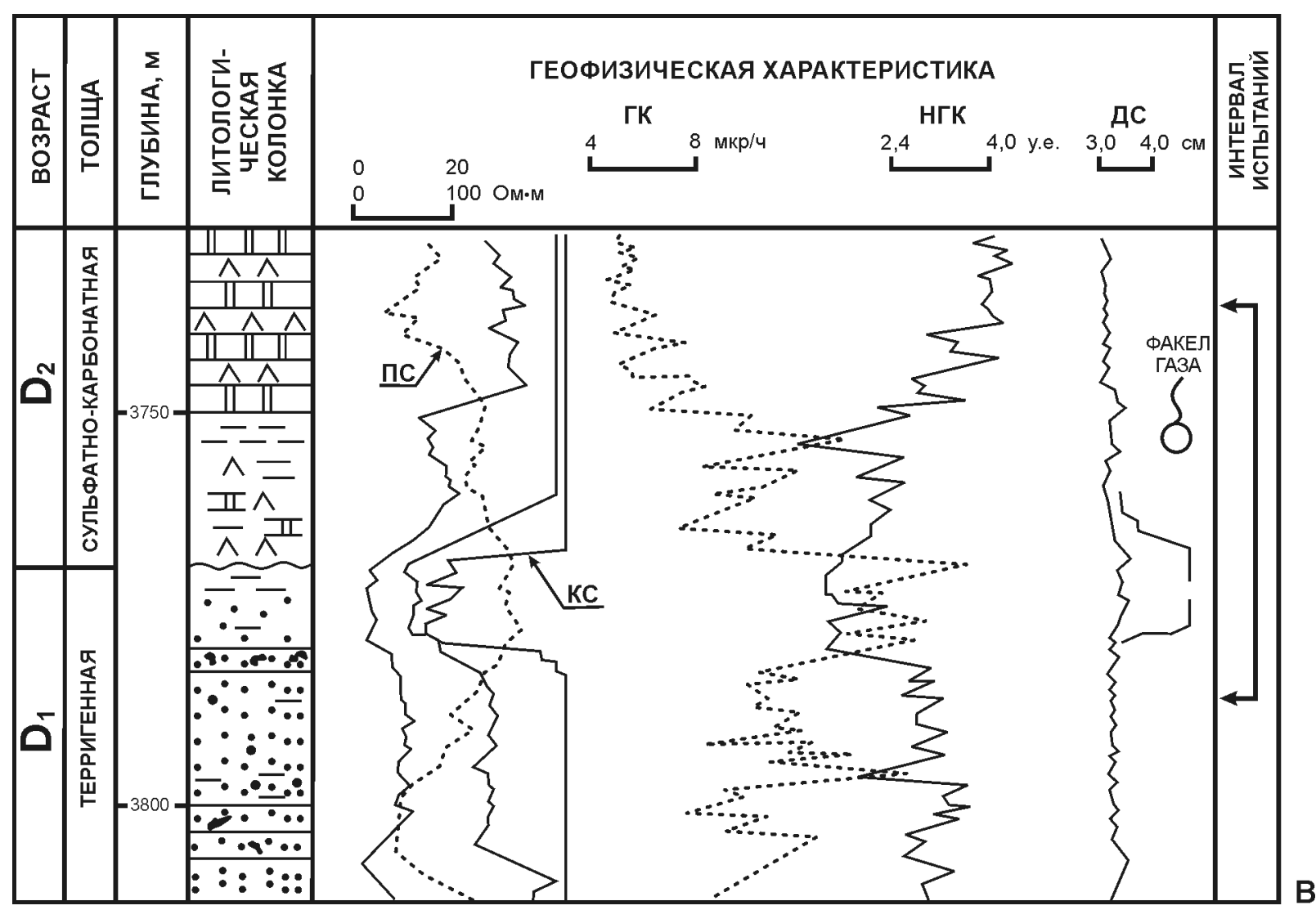

Рис. 1 продолжение. в - базальные толщи в сульфатно-карбонатной формации, Западное Причерноморье, Преддобруджский прогиб

представлен мелкими конгломератовидными и разнозернистыми песчаниками. Высокая продуктивность рассмотренных разноранговых базальных толщ обеспечивается трансгрессивным залеганием над ними глин, которые выполняют роль экранирующих покрышек, а также их хорошими коллекторскими свойствами. Однако, как показывают результаты изучения кернового материала и испытаний скважин, не все базальные толщи обладают высокой продуктивностью. Они могут быть непроницаемыми и не иметь коллекторских свойств даже, если будут сложены одними конгломератами и обломочными породами. Причиной этому является глинистый или карбонатный цемент пород, слагающих базальную толщу. Конгломераты и карбонатные обломки, сцементированные глинами, которые в своем составе содержат разбухающие смешаннослойные фазы (например, гидрослюдисто-монтмориллонитовые) - становятся непроницаемыми. В этом случае базальная толща с позиций нефтяной геологии и промысловой геофизики приобретает свойства так называемой «ложной покрышки» для подперерывных разуплотненных пород (возможных резервуаров УВ).

Базальные толщи ДДВ имеют разнообразный литологический состав, петрофизические свойства и образуются при различных условиях. В основании циклов широко распространенных терригенных формаций базальные толщи сложены грубообломочными гравийными и конгломератовидными разностями песчаных пород, выше которых залегают грубозернистые песчаники, затем песчано-глинистые породы застойных водоемов, еще выше - угольный пласт [8]. Перекрывается такая базальная толща пластом аргиллита (глины) нередко битуминозным с пиритом, еще выше залегают морские отложения. Подобное строение базальных толщ характеризует медленное наступление трансгрессии (рис. 1, б). В мощных карбонатных формациях мелководно-шельфового типа, которые также имеют циклическое строение, но сложены, как правило, только трансгрессивными членами эвстатических циклов, базальные толщи представлены преимущественно перемытыми и переотложенными обломками карбонатных пород с примесью глинистого материала. Нередко они сцементированы ангидритовым цементом, как это имеет место в девонской сульфатно-карбонатной формации Преддобруджинского прогиба (рис. 1, в). В карбонатных разрезах, расположенных 
на склонах депрессии базальные толщи могут перекрываться морскими глинами доманикоидных фаций, обогащенных ОВ, которые в сторону мелководного карбонатного шельфа выклиниваются. Примером может быть базальная толща в основании верхневизейского карбонатно-терригенного мезоцикла, которая перекрывается высокоуглеродистыми черными аргиллитами и мергелями доманикоидных фаций стыльской свиты, широко распространенными на территории южной окраины Складчатого Донбасса (см. рис. 2 в [10]).

Выделение разноранговых базальных толщ и перерывов в карбонатных разрезах, сложенных трансгрессивными членами циклов, требует специальных методических приемов и совместного использования материалов ГИС и керна [9]. По данным ГИС базальные толщи в основании карбонатных циклов характеризуются дифференцированной кривой кажущегося сопротивления (КС), значения которой несколько снижены по сравнению с ниже- и вышележащими породами, повышенными значениями естественной гамма-активности (ГК), снижением значений нейтронной-гамма-активности (НГК), каверна в стволе скважины регистрируются не всегда. Из карбонатных базальных толщ, которые обладают коллекторскими свойствами, могут быть получены притоки УВ, но, чаще всего, залежи нефти и газа приурочены к подперерывным разуплотненным участкам карбонатного разреза. Именно в этих зонах развиваются процессы эрозии, вызывающие изменение физических и коллекторских свойств карбонатных пород, при этом чаще всего наблюдаются трещиноватость, повышенная пористость, кавернозность, палеокарст.

Приведенные примеры не охватывают всего многообразия строения и вещественного состава базальных толщ, которые распространены в терригенных и карбонатных формациях упоминаемых здесь регионов. В.Д. Наливкин [13] отмечал, что литологический состав и условия, в которых формируются базальные толщи, зависят от последовательности эпох развития морского побережья. В этом развитии он выделяет 4 основных эпохи: денудации, прибрежной равнины, зоны прибоя, морского мелководья. Последовательность эпох зависит от величины поднятий, предшествующих трансгрессии моря. Когда море наступает на сушу с сильно расчлененным рельефом или скалистый берег, эпоха прибрежной равнины выпадает, и на породах материка сразу залегают брекчии и галечники зоны прибоя, а затем следуют отложения мелководья. Если же масштабы поднятий очень слабые и дно моря поднимается только до уровня морского мелководья, то на предшествующих отложениях будут залегать песчаники и глины с фауной морского мелководья, а отложения зоны прибоя будут отсутствовать. Многочисленные примеры образования базальных толщ по вышеизложенной модели В.Д. Наливкина, можно найти в разрезах девона и карбона северо-западной и юго-восточной прибортовых зонах ДДВ, которые отличаются широким развитием различных форм древнего рельефа.

\section{БАЗАЛЬНЫЕ ТОЛЩИ ДЕВОНСКОЙ И ПЕРМСКОЙ СОЛЕНОСНЫХ ФОРМАЦИЙ ДДВ}

В циклически построенных соленосных формациях базальные толщи, также как в терригенных и карбонатных разрезах, фиксируют перерывы в осадконакоплении, изменение режима седиментации и смену фациальных условий. Автономно или вместе с подперерывными разуплотненными породами нижезалегающего соленосного цикла (или породами кепрока при наличи таковых) базальные толщи могут обладать коллекторскими свойствами и содержать УВ.

В ДДВ соленосные формации девона и перми имеют ярко выраженное циклическое строение, изучением которого в разные годы занимались Н.Ф. Балуховский, В.К. Гавриш, Г.Н. Доленко, Л.И. Рябчун, Н.И. Галабуда, В.И. Созанский и др. В нефтяной геологии соленосные формации традиционно рассматриваются как «покрышки» (экранирующие толщи) для залежей УВ. Они также имеют корреляционное значение, так как в нефтегазоносных бассейнах прослеживаются на значительные расстояния. Не останавливаясь на известных примерах описания циклического строения соленосных формаций ДДВ, отметим следующее. Герцинскому мегациклу развития Припятско-ДнепровскоДонецкого прогиба соответствуют четыре соленосные формации: эйфельская, верхнефранская, верхнефаменская и нижнепермская. В основании мегацикла в его трансгрессивной части залегает базальная эйфельская морская соленосно-сульфатно-карбонатно-терригенная формация (имеет огромную площадь распространения: развита в юго-западной части Московской и восточной части Балтийской синеклиз, в Латвийской седловине, Припятской и Львовской впадинах). На ней трансгресивно залегают морские терригенные пестроцветные образования (старооскольские, пашийские и кыновские) и морская сероцветная карбонатная формация (саргаевская и семилукская). Все эти от- 

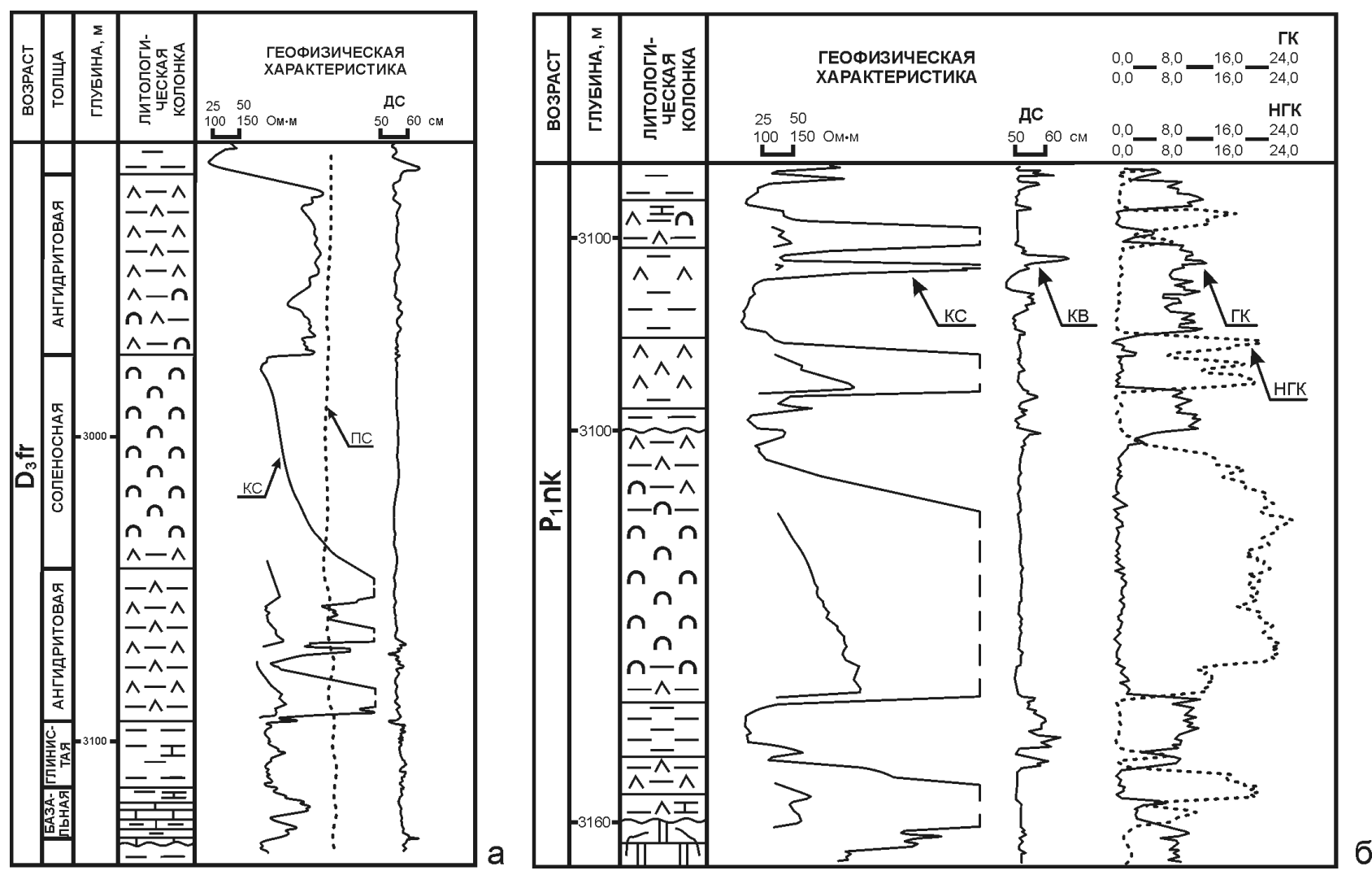

Pис. 2. Базальные толщи в соленосных формациях: а - ДДВ, Кинашевская площадь; б - ДДВ, Кобзевская площадь

ложения накопились в условиях трансгрессирующего обширного и мелкого эпиконтинентального морского басейна на стадии ранней синеклизы в обстановке медленного компенсированого слабо контрастного прогибания.

Состав базальных толщ трансгрессивных фаз соленосных циклов в девонской соленосной формации зависит от характера подстилающих пород. Преимущественно это глинистые известняки, доломиты, мергели или ангидриты (инт. 3115-3130 м на рис. 2, а). Интересно, что базальные толщи соленосных циклов, также как терригенных и карбонатных, перекрываются пластом морских (лагунных) глин. Дальнейшее продвижение лагуны фиксируется мергелистыми и глинистыми отложениями с тонкими прослоями глинистых известняков (инт. 3095- 3115 м ). Соленосный член цикла начинается одним или несколькими пластами глинистых ангидритов (инт. 3075-3095 м ). Соли залегают в средней части цикла, который завершается, как правило, глинистыми ангидритами, нередко разуплотненными и брекчированными (инт. 2920-2975 м ). Приведенное описание условно элементарного соленосного цикла характерно для девонской эвапоритовой формации ДДВ.

В пермской формации ДДВ соленосные циклы начинаются, чаще всего, глинистыми и/или брекчированными ангидритами (инт. 3149-3160 м на рис. 2,б), а при их отсутствии - только низкоомным глинистым пластом (инт. 3142-3149 м). В последенем случае, соленосные члены циклов, чередуясь с пластами глин, придают формации ритмичное строение. По нашему мнению ангидритовые базальные толщи могут быть коллекторами нефти или газа, поскольку они нередко трещиноваты и имеют пористость 8-10\% (например, инт. 2865-2866 м, 3157-3161 м в скв. Кобзевская-50). Подстилается пермская соленосная формация красноцветной - глинисто-песчаными отложениями картамышской свиты, в которой развиты нефтегазонасыщенные песчаные горизонты. Изучение цикличности пермской соленосной формации представляет интерес в связи с присутвием в верхней части циклов калийно-магниевых и магниевых солей, в частности, бишофита.

В девонских соленосных формациях большое значение имеет изучение кровли (или пород кепрока), где происходят размывы и развиваются длительные стратиграфические перерывы, с которы- 
ми могут быть связаны ловушки УВ. Так, например, на Скоробагатьковской площади Сребненского прогиба ДДВ предкарбоновый перерыв в кровле соленосного штока составил 25-27 млн. лет (на франской соли залегают песчаные нефтегазоносные горизонты верхневизейского возраста). В связи с вышеизложенным мы полагаем, что мощные соленосные разрезы в ДДВ, вскрытые многочисленными скважинами, требуют геологической переинтерпретации материалов ГИС с применением метода циклического анализа с целью повышения достоверности прогноза нефтегазоносности и других полезных ископаемых.

\section{выводы}

Выделение базальных толщ в основании циклических единиц разного ранга в сложнопостроенных терригенных, карбонатно-терригенных, карбонатных (карбонатно-сульфатных) и соленосных (соленосно-сульфатных) формациях позволяет детализировать строение разреза и более успешно коррелировать их по каротажным диаграммам. Выделение отсутствующих циклов или их частей позволяет определить местоположение перерывов, что важно для прогноза стратиграфических ловушек УВ.

Базальные толщи имеют свою иерархию. Их ранг определяется рангом седиментационного цикла, к основанию которого они приурочены. Эта же закономерность свойственна перерывам в осадконакоплении, которые ограничивают разноранговые циклы. Базальные толщи являются не только важным критерием цикличности разреза, но, также, представляют значительный практический интерес как коллектора повышенной емкости, которые могут содержать залежи нефти и газа.

Установленные закономерности в строении и геофизическая характеристика базальных толщ соленосных формаций позволяют определять их местоположение в разрезе на участках неохарактеризованных керном. Базальные толщи в соленосных циклах ДДВ могут обладать коллекторскими свойствами и служить реперами при корреляции разрезов по данным ГИС.

1. Архипов С.В. Тектонические циклы в развитии Сургутского свода, их базальные горизонты и нефтеносность // Вестник надропользователя. - 2003. № 17. $-\mathrm{C}$.

2. Балуховский Н.Ф. Геологические циклы. - Киев: Наук. думка, 1966. - 167 с.

3. Гавриш В. К., Егурнова М. Г., Зайковский Н. Я. и др. Циклостратиграфическая и литогеофизическая корреляция продуктивных горизонтов нижнего карбона и девона в связи с прогнозированием комбинированных ловушек углеводородов в ДДВ / АН УССР. Ин-т геол. наук. - Препр. - Киев, 1987. - 56 с.

4. Галабуда Н.И. Цикличность формирования Днепровско-Донецкой впадины. - К: Наукова думка, 1988. $104 \mathrm{c}$.

5. Доленко Г.Н., Бойчевская Л.Т., Галабуда Н.И. и др. Геологические формации нефтегазоносных провинций Украины. - Киев: Наук. думка, 1984. - 232 с.

6. Егурнова М.Г., Зайковский Н.Я. О перерывах в осадконакоплении в девонских отложениях ДДВ // Методика геофизических исследований на Украине. - Киев: Техніка, 1973. - С. 128-132.

7. Журавлев Е.Г. Геология и нефтегазоносный потенциал базальной формации // Материалы конф. «IV Губкинские чтения». - М.: ГАНГ, 1996. - С. 34.

Institute of Geological Sciences NAS of Ukraine, Kyiv, Ukraine Інститут геологічних наук НАН України , м. Київ, Україна
8. Зайковский Н.Я., Егурнова М.Г. Базальные толщи, их роль и значение в осадочном разрезе ДнепровскоДонецкой впадины // Киев: Техніка, 1973. С. 132-137.

9. Мачулина С.A. О седиментационной цикличности карбонатных комплексов сложного строения // Нефтяная и газовая промышленность. - 1990. - № 1. С. 9-12.

10. Мачулина С.А. Стыльская свита Донбасса - аналог черносланцевых формаций // Геологический журнал. - 2008. - № 2. - С. 52-61.

11. Мачулина С.А., Трофименко Г.Л., Рябчун Л.И. Цикличность осадконакопления и закономерности распространения карбонатных пород-коллекторов девонских отложений Западного Причерноморья // Геол. журн. - 1991. - № 1. - С. 131-141.

12. Мачулина С.О. Седиментаційна циклічність і методика вивчення девонсько-нижньокам'яновугільних нафтогазоносних відкладів Дніпровсько-Донецької западини / Автореф. дис. ... канд. геол.- минерал. наук, 1995. - 26 c.

13. Наливкин В.Д. Вопросы палеонтологии, стратиграфии, палеогеографии (избранные труды). - Ленинград: Наука, 1987. - 279 с. 